Anatolian Journal of Education

\title{
EVALUATION OF ESSAY WRITING AMONG SENIOR SECONDARY SCHOOL ARABIC STUDENTS IN KWARA STATE, NIGERIA
}

\author{
Musa Siddiq ABDULLAHI* \\ Department of Arts Education, Faculty of Education, University of Ilorin, \\ alfulaty2013@gmail.com \\ Musa SALISU** \\ Department of Arts Education, Faculty of Education, University of Ilorin, \\ salisumusa95@yahoo.com
}

\begin{abstract}
This study evaluated essay writing among Senior Secondary School Arabic students in Kwara State, Nigeria. This study evaluated the content, organization, expression and mechanics aspects of essay writing among senior secondary school Arabic students on the basis of gender and school ownership in Kwara State, Nigeria. A total number of 174 students were sampled using cluster sampling technique because few students offer Arabic Language at Senior Secondary School in the state. 2013 West African Senior School Certificate Examination (WASSCE) Arabic essay writing test was adapted for data collection while descriptive statistics of mean and standard deviation were used to answer the research questions, the null hypotheses were tested with the use of inferential statistics of t-test. Findings from the study revealed among others, that the proficiency of senior secondary school Arabic students in the content, organization, expression and mechanical accuracy aspects of Arabic essay writing was below average in Kwara State, Nigeria. Findings also revealed that, there was no significant difference in the proficiency of Arabic students in essay writing on the basis of gender and school ownership in Kwara State. It was then recommended among others, that students should be constantly engaged in reading textbooks and story books such as novels, newspapers, etc. as well writing stories, letters, and articles. This might help to improve their proficiency in outlining and constructing good contents, organization, expression, as well as fine-tuning and perfecting their mechanics in essay writing.
\end{abstract}

Keywords: Evaluation, Essay Writing, Arabic Students, Kwara State, Nigeria

\section{Introduction}

Arabic language is the language of the holy Qur'ān. Today, it is the most important language of the Semitic group spoken by millions of people and understood by many more throughout the world. The Arabic writing system has an alphabet of twenty-eight consonants, three long vowels and three short vowels. Its writing system is from right to left and was introduced in Makkah not long before the holy Qur'ān was revealed. 
Historically, Arabic is regarded as the oldest foreign language in Nigeria today. This is because its entry into the country dated back to the seventh century of the Christian era and the first century of the Hijrah calendar. Centuries before the advent of Europeans in Nigeria, Arabic Language had been used for religious, social and cultural purposes in the Northern Nigeria. It was in recognition of its significance that Arabic language is introduced into the Nigerian educational curriculum as an academic discipline. In Nigeria today, three languages (Hausa, Igbo and Yoruba) have been raised to the status of official languages in addition to English, which is the nation's official language, Arabic and French are also taught in Nigerian schools as foreign languages and elective in status (Mahmud, 2012).

Essay writing as an integral part and the most complex aspects of secondary school Arabic Language curriculum by which students are required to perform well in it as it attracts significant marks. Essay writing is a piece of writing that methodically analyses and evaluates a topic or issue (Guo and Ouyang, 2010). Fundamentally, an essay is designed to get your schorlarly opinion on a particular matter. The teaching of essay writing is designed to help develop the creativity of individuals or train them on how to relate their experiences or contribute to current issues around their immediate environment and the world at large (Cai and Dai, 2001). A good performance in essay writing is very important in the educational advancement of students in learning Arabic Language.

Essay writing involves the development of a designed idea (content), organisation skill, expression, and mechanical accuracy, the capture of mental representations of knowledge, and of experience with Arabic grammar. The interlocking processes of writing by novice and expert authors have been studied by such diverse disciplines as cognitive psychology, stylistics, rhetoric, text linguistics, critical literary theory, hypertext theory, second language acquisition and writing pedagogy (Horvath, 2001). Extensive reading is necessary for the development of writing skill with comprehensive input for organisational and grammatical improvement that occur in essay writing. Krashen (1993) concluded that formal instruction of sentence-level rules can improve writing ability. For significant and successful writing development to occur, this may only be a complement to receiving a comprehensive input via reading.

Evaluation of Arabic students' essay writing involves the procedures or yardsticks for judging students' write-up. This is simply referred to as marking scheme. There are different scales for evaluating students' essay writing but commonly in Nigeria, it is judged in terms of the writer's success in achieving the purpose of writing (be it to entertain, instruct, inform, demolish or persuade) and based, in varying degrees of factors such as adequacy of the treatment of the subject matter, originality of the approach, appropriateness of the language, clarity of the exposition, narration or argument, balance and mechanical accuracy (WAEC, 2014). These factors are grouped into a number of well-defined aspects with a maximum mark for each aspect as;

i. Content (10 marks)

ii. Organisation (10 marks)

iii. Expression (10 marks) and

iv. Mechanical Accuracy (10 marks).

The content aspect of essay writing involves the generation of relevant points or ideas to the topic or central theme and its specific audience and purpose. In content, the appropriateness of the language and adequacy of the treatment of the subject matter as well as the originality in the approach are all 
important. West African Examinations Council (WAEC, 2014) asserted that when each relevant point in the content is developed and made a paragraph consisting at least five lines attracts extra mark(s). The organisation aspect of essay writing involves correct use of formal attributes such as the proper arrangement of ideas, good paragraphing, appropriate use of emphasis, etc. In organisation aspect, a suitable opening, adequate development, balance, coherence and suitable conclusion are very important. Also, paragraphs are expected to be chronologically, spatially plausibly, logically and understandably coherent (WAEC, 2014).

The expression aspect of essay writing involves clarity and general appropriateness/structure of sentences, use of vocabulary and figurative language, skillful and sophisticated use of punctuations. However, the evaluators or examiners are expected to be unduly influenced by mechanical errors when awarding mark(s) for expression aspect. This is perhaps a problem to students as many of them suffer from restricted vocabulary and inadequate exposure to idiomatic expression (Lauren, 2014). According to Wang (2013), many sentences are direct translation of mother-tongue resulting in numerous un-Arabic grammatical collocations which has been the attribute of the neglect to extensive reading.

The Mechanical Accuracy aspect involves complying with the rules of grammar, punctuation and spelling. Students are expected to make use of skillful and sophisticated ways of punctuations to avoid those errors embedded in the mechanical accuracy aspect of essay writing.

Gender as distinct from "sex" refers to socially-constructed and not biological-defined characteristics of human beings. It refers to the social construction of what is considered male and female based on socio-cultural norms and power. Adamu (1990) argued that gender is a factor that may influence effectiveness of an educational programme. Ezeh (2013) observed that gender describes the personality traits, attitudes, behaviours, values, relative power, influence roles and expectation (femininity \& Masculinity) that society ascribes to the two sexes on differential basis. Eugene (2016) viewed gender as a psychological term and a cultural construct developed by society to differentiate between the roles, roles, behaviour, mental and emotional attributes of males and females.

\section{Statement of the Problem}

Apart from students finding it difficult to generate, organise and express ideas in essay/letter writing, grammatical errors such as wrong tense; omission of article; misuse of modal operators, countable and uncountable nouns; errors in concord; punctuation errors such as wrong use of comma; full stop; column/semi column; question mark; exclamation mark, etc, are mistakes commonly committed by students in the course of Arabic writing essay in an examination. As a result, students are penalised by deduction of half mark from each error made. The massive failure rate in essay writing exhorted the researcher into this study. Thus, this study was set out to evaluate essay writing among Senior Secondary School Arabic students in Kwara State, Nigeria.

\section{Purpose of the Study}

This study evaluated essay writing among Senior Secondary School Arabic students in Kwara State, Nigeria. Specifically, it evaluated the content, organization, expression and mechanical accuracy aspects of essay writing among Senior Secondary School Arabic students on the basis of gender and school ownership in Kwara State, Nigeria.

\section{Research Questions}

The following research questions were answered. 
1.What are students' proficiencies in Arabic Language essay writing in Kwara State, Nigeria?

2. Is there any significant difference between students' proficiencies in Arabic Language essay writing on the basis of gender in Kwara State?

3. Is there any significant difference between students' proficiencies in Arabic Language essay writing on the basis of school ownership in Kwara State?

\section{Research Hypotheses}

The following hypotheses were tested.

$\mathbf{H o}_{1}$ :There is no significant difference in the proficiency of students' performance in Arabic essay writing on the basis of gender.

$\mathbf{H o}_{2}$ : There is no significant difference in the proficiency of students' performance in Arabic essay writing on the basis of school ownership.

\section{Method}

This study employed descriptive survey design. The population for the study covered all Senior Secondary School Arabic students in Kwara State, Nigeria. The target population was all Senior Secondary 3 (SS III) students that have registered for Arabic Language in Senior School Certificate Examination (SSCE). Cluster sampling technique was used to sample 174 students that registered for Arabic Language in the State as the respondents, because not all schools and students in the state offer Arabic Language at the Senior Secondary School level. Therefore, all students that registered for Arabic Language in the 2016 WASSCE in the state were used as the respondents. WAEC 2014 essay writing was adapted and used as the Arabic Performance Test (APT) for data collection. The West African Senior School Certificate Examination (WASSCE) Arabic essay questions are assumed to be products of standardized examinations. Descriptive statistics of mean and standard deviation was used to answer research question one, while research questions two and three with corresponding hypotheses one and two were tested with the use of inferential statistics of the t-test at 0.05 alpha level.

\section{Findings}

\section{Answering of Research Question}

\section{Table 1}

Students' Proficiency Arabic Language Essay Writing in Kwara State, Nigeria

\begin{tabular}{lllll} 
& Mean & S.D & Minimum & Maximum \\
\hline Content & 4.46 & 1.99 & 2.00 & 7.00 \\
Organization & 3.90 & 1.88 & 1.00 & 6.00 \\
Expression & 6.64 & 3.23 & 3.00 & 17.00 \\
Mechanical & 2.43 & 1.43 & 0.00 & 6.00 \\
accuracy & & & & \\
Grand Mean & $\mathbf{6 . 0 2}$ & & & \\
\hline
\end{tabular}


As shown in table 1, students had the mean score of 4.46, 3.90, 13.27 and 2.43 with minimum score of 2.00, 1.00, 3.00, 0.00, and maximum score of 7.00, 6.00, 17.00, 6.00 in the content, organisation, expression and mechanical accuracy aspects of the essay writing respectively. The grand mean 4.28 obtained shows that the proficiency of students in Arabic Language essay writing is below average in Kwara State, Nigeria.

\section{Hypotheses Testing}

Hypothesis One: There is no significant difference in the proficiency of students' performance in Arabic Language essay writing on the basis of gender in Kwara State, Nigeria.

Table 2

Difference in the Proficiency of Students' Performance in Arabic Language Essay Writing on the Basis of Gender

\begin{tabular}{cccccccc}
\hline Gender & No. & Mean & S.D. & df & t-value & Sig. & Remark \\
\hline Male & 145 & 59.13 & 8.53 & & & & \\
& & & & 172 & 2.75 & 0.59 & \\
Female & 31 & 66.01 & 7.45 & & & & \\
\hline
\end{tabular}

*Insignificance at $\mathrm{p}>0.05$

Table 2 shows the t-value of 2.75 obtained with a p-value of 0.59 computed at 0.05 alpha level. Since the p-value of 0.59 is greater than 0.05 alpha level, the null hypothesis one is retained. This implies that there is no significant difference in the proficiency of male and female Arabic students' performance in Arabic language essay writing in Kwara State, Nigeria $\left(t_{(172)}=2.75, p>0.05\right)$.

Hypothesis Two: There is no significant difference in the proficiency of students' performance in Arabic Language essay writing on the basis of school ownership in Kwara State, Nigeria.

Table 3

Difference in the Proficiency of Students' Performance in Arabic Essay Writing on the Basis of School Ownership

\begin{tabular}{lccccccc}
\hline $\begin{array}{l}\text { School } \\
\text { Ownership }\end{array}$ & No. & Mean & S.D. & df & t - v a l u e & Sig. & Remark \\
\hline Public & 101 & 62.42 & 7.44 & & & & \\
& & & & 172 & 2.79 & 0.48 & NS \\
Private & 73 & 57.46 & 8.69 & & & & \\
\hline
\end{tabular}

Table 3 shows the t-value of 2.79 obtained with a p-value of 0.48 computed at 0.05 alpha level. Since the p-value of 0.48 is greater than 0.05 alpha level, the null hypothesis two is retained. This implies that there is no significant difference in the proficiency of public and private school Arabic students' performance in essay writing in Kwara State, Nigeria $\left(\mathrm{t}_{(172)}=-2.79, \mathrm{p}>0.05\right)$. 


\section{Discussion}

Finding from the study revealed that students' performance in Arabic Language essay writing was relatively fair in Kwara Central, Nigeria. Given that students' Arabic essay writing was evaluated in the areas of content, organisation, expression and mechanical accuracy (COEM), the proficiency of students in the content aspect of the essay writing was below average as the mean score obtained for the contents was 4.46 out of 10 marks apportioned to it. The proficiency of students in the organisation aspect was also very low with the mean score of 3.90 out of 10 marks. However, students' proficiency in the expression aspect was relatively high as the mean score is 6.64 out of 10 marks apportioned to it was above the average. Results showed that the proficiency of students in the 'mechanical accuracy was generally very low with students having the mean score of 2.43 out of 10 marks. This finding is corroborated by Lado (2004) who affirm that students' proficiency in Mechanical Accuracy is streamlined on the students' inadequate knowledge of punctuations' marks and how often the students write which determines the success or failure in the essay writing. The grand mean 4.28 obtained signified that the general proficiency of students in Arabic essay writing was below average in Kwara State, Nigeria.

Findings of this study also revealed that there was no significant difference in the proficiency of male and female students in Arabic Language essay writing in Kwara State, Nigeria $\left(\mathrm{t}_{(766)}=0.75, \mathrm{p}>0.05\right)$. This means that the proficiency and aptitudes of male and female Arabic students are the same in essay writing in the state. This is supported by Abdullahi (2016) who affirmed that significant difference does not exist in the performance of male and female Arabic students in Kwara State. Results also showed that there was no significant difference in the proficiency of students from public and private schools in Arabic essay writing in Kwara State. $\left(t_{(766)}=-0.79, p>0.05\right)$. This means that the proficiency and aptitudes of students from public and private schools are the same in the Arabic Language essay writing in the state. These are supported by Adegbija (1977). Who emphasized that exposure, environment and reinforcement are most likely to bring about the same capabilities in male and female students in the public and private schools in Kwara State.

\section{Conclusion}

Given the findings of this study, it is evident that various factors are responsible for students' poor performance in Arabic Language essay writing. These problems are students and teachers oriented. These include lack of interest in writing, poor reading habit and habits, students' inability to express themselves in good and acceptable Arabic. It was therefore concluded that the proficiency of students in the content, organisation, expression and mechanical accuracy aspects of Arabic Language essay writing was below average in Kwara State, Nigeria. It was also concluded that the proficiency and aptitudes of both public and private students are the same in Arabic essay writing as there is no significant difference in the proficiency of male and female Arabic students from public and private schools in the Arabic essay writing in the State.

\section{Recommendations/Suggestions}

Based on the findings from this study, the followings are the recommended:

1. Students should be constantly engaged in reading Arabic story books such as novels, newspapers, etc. as well as writing story, letter, etc, in Arabic. This would help to improve their proficiency in outlining and constructing good contents, organisation, expression, as well as finetuning and perfecting their mechanical accuracy in Arabic essay writing. 
2. Teachers should undertake regular and ongoing assessment to identify any difficulty that students might be experiencing in Arabic essay writing and provide consistent feedback to ensure that students are making progressing in the content, organisation, expression and mechanical accuracy.

3. School administrators should establish regular quiz, puzzle and debate among students and tailor it to broadening their proficiency in essay writing in Arabic.

4. Parents can also assist by ensuring that their children read and speak Arabic at home, employing teachers for extra classes when needed in order to boost their performance in essay writing.

5. Government should put in place programmes that are meant to reward students who perform well in Arabic essay writing and more educational programmes that can enhance communication skills should be introduced over the radio and television programmes.

\section{References}

Abdullahi, M.S. (2016). Effect of visual resources on the academic performance of upper-basic students in Arabic language in Ilorin metropolis. Journal of Education in Developing Areas. 24(1). 319-327. www.jeda-uniport.com

Adamu, S. (1990). Job satisfaction and effectiveness among English and Mathematics teachers in Edu Local Government Area. Unpublished M.Ed. Dissertation. University of Ilorin, Ilorin.

Cai, L. Q., \& Dai, W. D. (2001). The integration of error classification. (Foreign Language World, 4, 52-57).

Eugene, U.O. (2016). Influence of gender and location on students' achievement in chemical bonding, Department of Science Education, University of Nigeria, Nsukka.

Ezeh, D.N. (2013). Science without women: a paradox. $75^{\text {th }}$ inaugural lecture of the university of Nigeria, Nsukka: University of Nigeria senate ceremonials committee

Guo, X. H. \& Ouyang, J. (2010). A new exploration of college English writing based on error analysis theory. Foreign Language and Literature, 26(2), 137-140.

Horvath J. (2001). Advanced writing in English as a foreign language. Published by Lingua Franca Csoport. Applied Linguistics Department of the university, University of Pecs

Krashen, S. (1993). The power of reading: Insights from the research. Englewood: Libraries Unlimited.

Lauren, H. (2014). How to write an essay in linguistics \& English language. University of Edinburgh

Mahmud, A.A. (2012). The Arabic language: Its relevance to Nigerian development.

European

Scientific Journal, Vol8, No.26. Pp192-202.

Wang, M. (2013). An empirical study on the writing ability of college students with the error analysis approach. English Language and Literature Studies; 3, (2); 54 - 61

West African Examinations Council (2014). May/June 2014 WASSCE final marking scheme Arabic language 2: General Note on the Marking Composition.AfriPAF.com. 